\title{
THE INTERCULTURAL COMPETENCE OF A NEW UKRAINIAN SCHOOL TEACHER AS AN IMPORTANT FACTOR OF EFFECTIVE PEDAGOGICAL ACTIVITY
}

\author{
T. Branitska, N. Logutina
}

В статті обтрунтовано актуальність проблеми підвищення рівня міжкультурної компетентності вчителів нової української школи в умовах розмаїття етнокультурного простору. Розкрито поняття: міжкультурної компетентності особистості, міжкультурної компетентності фахівия, міжкультурної компетентності вчителя нової украӥнської школи як складових професійної культури; проаналізовано їх особливості, зумовлені специфікою професійної діяльності. Доведено багатофункиіональність та багатовимірність міжкультурної компетентності педагога; обтрунтовано структурні компоненти та критерії визначення їх сформованості: иіннісно-етичний (ціннісне ставлення до педагогічної діяльності, розуміння особливостей етнокультурних спільнот, світоглядна позиція, дотримання етичних норм педагогічної діяльності, людино/дитиноцентризм); теоретико-когнітивний (спеціальні фахові знання, здатність до розумової (мисленнєвої) діяльності, інтелектуальні здібності); особистісно-психологічний (професійно важливі якості особистості- уважність, спостережливість, чутливість до емоційного стану співрозмовника, емпатія, емочійна стійкість, альтруїзм, послідовність, справедливість, вимогливість); мовно-комунікативний (мовна, комунікаційна культури, лінгвістичні здібності, уміння слухати та чути, толерантність, тактовність); прочесуально-діяльнісний (володіння методикою викладання предмету, уміння та навички, організаторські здібності, швидкість реакиї та прийняття виваженого рішення, відповідальність, здатність до рефлексії та самовдосконалення).

Визначено власну візію щзодо міжкультурної компетентності вчителя як особливого інтегративного внутрішнього утворення,що забезпечує готовність педагога до професійної діяльності в умовах сучасного етнокультурного розмаїття освітнього середовища та трунтується на гуманістичних, моральноетичних, духовних цінностях, гносеологічних та світоглядних позиціях.

Розглянуто питання формування міжкультурної компетентності вчителів у закладах вищої освіти та ї̈ удосконалення у закладах післядипломної педагогічної освіти в контексті ідей самоосвіти, саморозвитку на підгрунті основоположних підходів: системному; компетентнісному; культурологічному; полікультурному. Окреслено шляхи та способи підвищення ефективності педагогічної діяльності.

Також зазначено, щзо рівень сформованості міжкультурної компетентності особистості фахівців сприяє не тільки підвищенню ефективності їхньої фахової діяльності в Украӥні, але й збільшує вірогідність трудової міграчії висококваліфікованих фахівиів.

Запропоновано способи, якщо не запобігання, то мінімізації “витікання мізків”, трудової мігращії з Украӥни у зв'язку з процесами циввілізаційної глобалізації світового простору

Ключові слова: глобалізація, комунікація, міжкультурна компетентність, міжкультурна компетентність вчителя, ефективність педагогічної діяльності

Copyright (C) 2020, T. Branitska, N. Logutina.

This is an open access article under the CC BY license (http://creativecommons.org/licenses/by/4.0).

\section{Introduction}

In the XX-XXI centuries in the world noticeable tendency for migration of individuals, ethnic groups, there is a civilization globalization, which leads to increased processes of intercultural communication in various spheres of life: social, economic, political, educational, increasing international tourism, making it possible to: get education abroad, international cultural exchanges; the establishment of a cultural and sociocultural space, in which representatives of different cultures and ethnicities can harmonious coexist, which is very relevant for the modern civilized world.

In today's Ukrainian society, especially in the last 5-6 years, when in the east of Ukraine the AntiTerrorist Operation (Operation of the United Forces) is ongoing, migration takes place inside the country in the form of internally displaced persons with families, relatives, children from Crimea and Donbass. These families from the east of Ukraine and the Crimea, in the hope of temporary, sometimes permanent, accommodation are located in all regions of our country, they are forced to adapt not only to new living conditions, but also to the peculiarities of the new social environment, other traditions, ethnoculture of society. We believe that, as a result of life experience, interaction and communication skills, adult family members are gradually adapting to new living conditions. An attentive, observant, competent caregiver, teacher and responsible parents will be able to help a child also painlessly undergo adaptation. According to the latest census (2001), 
134 nationalities (ethnicities) live in Ukraine. Therefore, the problem of increasing the level of intercultural competence and communication of members of society is urgent in our time, and the question of formation and development of the intercultural competence of a modern teacher of a new Ukrainian school is especially important. Educating the humanistic outlook of children, promoting understanding, perception and respect for various ethno-cultural, social, religious characteristics of others, prevention and avoidance of conflicts, misunderstandings on an ethnic basis are an important task and mission of the teacher of the new Ukrainian school.

Culture, its development, achievement as a component of modern civilization in the conditions of globalization and integration of Ukraine into the world community promotes conflict-free interaction, mutual understanding between representatives of different ethnic groups, communities on all aspects of interaction - moral-value, creative, educational, informational and political.

\section{Literary review}

The problem of interpretation of categories "competence", "competency", "professional competence", worried the minds of scientists of different eras, different fields of knowledge: psychological, pedagogical, sociological, economic, technical.

Modern researchers of professional competence, cognitive-acmeological competence, pedagogical competence $[1,2]$ have differentiated generic concepts. "Competence" is interpreted as an integral personal characteristic of the specialist, and "competency" is its structural elements and allows successful completion of certain or all tasks in the professional activity [1]. And the level of professional competences in the educational sphere of activity is determined by three main indicators: epistemological, which implies the formation of scientific and practical knowledge; axiological, which is based on the value-motivational orientations of the individual and his/her activity; practical, that is, the capacity for practical, effective activity [2].

Intercultural competence, ways of its formation, intercultural communication, philosophy and psychology of communication, interethnic tolerance are the subjects of research among the Ukrainian scientists [3, 4]. Considerable interest in understanding the significance of the topic of the study, analysis of specific features of the teacher's intercultural competence, systematization of approaches to its formation is given to works: [5] on cultural ethnopedagogy, teachers' readiness to work in the conditions of diversity of the modern ethnocultural space, organizational forms and methods of formation of future educators' tolerance for manifestations of another culture; [6] as for understanding and substantiating the importance of forming the intercultural competence of the teacher as a factor in the effectiveness of pedagogical activity in general; [7] on current trends of intercultural interaction, peculiarities of communication culture of different social groups in the conditions of multinational Ukrainian society, development of cultural potential of specialists; [8] concerning the development of the ethical teachers' competence, which reflects the inner culture, spirituality, morality, the ability to make decisions and actions that conform to the norms of culture, and are the basis for the implementation of the humanistic paradigm of education; works [9] on the development, realization of the competence in the modern society;

We consider topical studies of the evolution of the development of views on the categories "competence", "competency", "professional competence", "intercultural competence" from the founders to the present, which will make it possible to systematize, generalize, differentiate and identify new facets, features of these phenomena. A systematic look at the interrelation of the intercultural competence with the teacher's professional competence in the context of civilization globalization and migration of society will make it possible to analyze changes in the functional activity of teachers of the new Ukrainian school. Such research will help to identify and improve methods for developing the intercultural competence to address the problem of preparing teachers to work in a multicultural educational environment.

The problem of development of the intercultural competence of elementary school teachers in the context of civilization globalization and intra-state migration of the population of Ukraine is urgent as a factor in reducing the negative consequences, caused by these circumstances. Our research is aimed at defining features, structural components, conceptual approaches to the formation of the intercultural competence of elementary school teachers in the aspect of the education system of the new Ukrainian school.

\section{The aim and objectives of the study}

The aim of the study was to substantiate: peculiarities of the intercultural competence of the teacher of the new Ukrainian school as an important factor of effective pedagogical activity; basic approaches to the system of formation of the intercultural competence of teachers in higher education institutions, its improvement in postgraduate teacher education in the context of ideas of selfeducation, self-development throughout life.

To achieve this aim, the following objectives were set:

1. Explain and differentiate the concepts of "competence", "competency", "professional competence", "intercultural competence of the individual" as a member of a particular community, the carrier of its ethnoculture.

2. Outline our own vision of the intercultural competence of the new Ukrainian school teacher.

3. Identify and justify: features of the teacher's intercultural competence; structural components, fundamental approaches to the system of formation of the teacher's intercultural competence.

4. Identify ways to improve the effectiveness of pedagogical activity in the conditions of diversity of the ethno-cultural environment.

5. Prove that the multi-vector of continuous education, self-education, self-improvement throughout life is an important condition for slowing down / stopping labor migration from Ukraine.

\section{Research methods}

Theoretical (analysis, systematization, classification, generalization of studies of domestic and foreign scientists on the concepts of "competence", "competency", "professional competence", "intercultural compe- 
tence", which allows you to get an idea of the state of development of the research problem, determine our own vision of the problem and make conclusions); empirical (observation of the educational process, study of the teachers' experience in Vinnitsa region schools, as well as outstanding teachers of the past and present to identify and accumulate factors that affect the effectiveness and productivity of pedagogical activity.

\section{Results of the investigation}

Before presenting our own thoughts, views and opinions regarding the intercultural competence, in particular, intercultural competence of a teacher of the new Ukrainian school, it is necessary to define the concept of intercultural competence, clearly distinguish between "competence", "competency", "professional competence". Difficulties in interpreting the terms "competence" and "competency" are due to their etymological closeness: "competentia" in English - (rightly ...) and "competens" (capable of...).

In practical production and management activities, "competence" defines the range of powers, rights and obligations of an official to make decisions, organize their implementation, control and be responsible; "Competency" - the ability of the individual, his/her awareness, based on knowledge, skills and experience to perform certain professional tasks, to activity [10]. "Competency", "... implies not so much the availability of a significant amount of knowledge and experience, but the ability to update this knowledge and experience at the right moment in order to exercise their professional functions" [11]. It is noteworthy, that the group of researchers [6] consider the relationship between competence and competency, that the concept of "competence" reflects the content of a particular activity, and "competency" - a set of personality traits, necessary to implement this content, as well as a set of knowledge, skills, and experience that allow an individual to effectively solve problems in a particular field of life. Therefore, "competence" is a set of objective conditions that determine the possibilities and limits of exercising a competency [6].

Therefore, the components of the competency of the specialist personality are knowledge, skills and experience in the future professional activity. We believe that for a successful professional activity, a specialist also needs personal qualities: a creative approach to the goal, tasks, methods, techniques of activity, based on knowledge and developed intelligence; orientation and ability to the chosen type of activity; analytical, critical thinking, flexibility of thinking; ability to communicate; independence, perseverance, determination; orientation to introspection, selfcriticism, self-improvement. Thus, the components of a competence of the personality of the specialist: cognitiveinformation, personal, activity-procedural, reflexive.

"Professional competence" is interpreted as: the psychological readiness of the specialist for the activity (personal characteristics of the individual); theoretical readiness (the ability to think logically, critically, analyze, summarize, have knowledge); practical readiness (skills - organizational, communicative) [12].

The professional competence of the teacher, which is formed and manifested in his/her activity, is defined as the ability to successfully perform functions and to act in various situations, as a willingness to selfdevelopment in the face of constant changes in society. Its level depends on the breadth of formats of contexts for solving professional problems and serves as a means of realizing the personal meanings of the teacher [13].

It is important to note, that in the context of civilizational globalization of all spheres of human life, a significant component of the professional competence is the intercultural competence of the personality and personality of the specialist.

The intercultural competence of the individual is "a prerequisite for successful integration of the individual into the world society; a factor in reducing the negative effects of globalization, a condition that enables effective interaction in the process of intercultural communication" [6]. In the view [10], intercultural competence is a "body of knowledge skills, abilities, common to all participants of communication, necessary to achieve mutual understanding".

In the context of intercultural interaction, knowledge and skills should be combined with openness, the flexibility of one's thinking, as well as the motivated desire of the individual to communicate effectively and build relationships successfully. Intercultural competence is the ability to recognize, respect and effectively use differences in the perception, thinking, and behavior of representatives of one's and another's culture in intercultural contacts [4].

The intercultural competence of specialists "reflects the philosophical, cultural, psychological, ethnological and other aspects of their preparation, at the center of which are the issues of culture and the inner world of a person" [3]. Therefore, the intercultural competence becomes the property of the individual or community, which allows partners to perform joint activities, create common cultural values, form a single sociocultural space, in which representatives of different cultures and ethnicities can interact [10].

Intercultural competence is a mechanism for harmonizing social relations between different groups, between representatives of different ethnicities and cultural traditions, as well as a mechanism for harmonizing interpersonal relations in a multicultural professional environment only in the process of communication [7].

Researcher [14] argues that communication is the process of exchanging thoughts, views, information, feelings between two people or a group of people. Communication is an art. It is necessary to possess it in all spheres of life, professional or personal. To master the art of communication, you need to practice, improve knowledge and gain experience.

In the age of civilization globalization, intercultural communication with other cultures is inevitable. Internet technologies have increased the likelihood that everything that is documented on the Internet will be read by someone with another culture. Intercultural communication is important in any field of activity, so the level of formation of the art of communication with other cultures is an important criterion for the professional skill of a specialist, especially for teachers of the new Ukrainian school [15].

Therefore, the main criteria for determining the level of formation of the intercultural competence of 
the individual is his/her ability to: effectively carry out intercultural interaction on the basis of knowledge of communication psychology; understand and respect national and ethnic characteristics of other cultures; to be aware of the ethnic community; perceive the totality of conditions and circumstances of intercultural dialogue as a condition of self-enrichment, selfimprovement and self-realization of carriers of different cultures.

It is important to note, that the phenomenon of intercultural competence is multifunctional, because in the process of intercultural activity and communication it is necessary and possible to solve problems: at different levels of life; in different situations of a globalized ethnocultural society, amortizing the challenges of civilization globalization. The intercultural competence of professionals as a phenomenon is also multidimensional, because the criteria for its formation are: linguistic, psychological and professional knowledge, skills, experience; perception and understanding: systems of national, general, cultural, ideological values; historical origins of regional, national-linguistic, ethno-psychological, religious-confessional, cognitive-informative features; traditions, moral and ethical norms of behavior, value attitudes of carriers of different cultures.

As a result of the analysis, generalization of scientific researches concerning the phenomenon of "competency", we have defined our own vision that the intercultural competence of the teacher is a special integrative internal education, which ensures the teacher's readiness for the professional activity in the context of modern ethno-cultural diversity of the educational environment and soil moral, ethical, spiritual values, epistemological and ideological positions. We believe that the intercultural competence of the teacher is the organic unity of interconnected and integrally interdependent cultures: worldview, spiritual, linguistic, communicative, conflicting, culture of thinking, feelings, behavior in unison with professional and pedagogical knowledge, skills, is a significant potential in teaching.

Regarding the structural components of the teacher's intercultural competence in the context of interethnic interaction, we have distinguished the following:

1) value-ethical (value attitude to the pedagogical activity, understanding of characteristics of ethnocultural communities and respect for them, world-view, observance of ethical norms of the pedagogical activity, person / child-centrism);

2) theoretical and cognitive (special professional knowledge, ability to think (thinking) activity, intellectual ability);

3) personality-psychological (professionally important qualities of personality - attentiveness, observation, sensitivity to the emotional state of the interlocutor, empathy, emotional stability, altruism, consistency, justice, demandingness);

4) linguistic and communicative (linguistic, communication cultures, linguistic abilities, ability to listen and hear, tolerance, tact);

5) procedural activity (possession of the method of teaching the subject, skills, organizational skills, speed of reaction and decision-making, responsibility, ability to reflect and self-improvement).
Intercultural competence of the teacher of NUS (new Ukrainian school) is one of the main professional competences, an important factor for success and perfection in the pedagogical activity, and also an essential component of the professional competence, along with natural abilities, personal psychological characteristics and readiness for the pedagogical activity.

Since in the educational process the teacher is a key figure, and knowledge is the driving force in all spheres of human life, in particular, the formation and development of the intercultural competence of future teachers of the new Ukrainian school is a priority task of higher education institutions and institutions of postgraduate education under conditions of the modern society diversity. Education creates favorable conditions for the preservation and transformation of the cultural identity of different social communities, contributes to: the development of critical perception of the personality of the surrounding reality; preserving cultural diversity.

The system of higher education of Ukraine in the conditions of intensification of social development is aimed at training the highly qualified, competitive teacher, capable of nurturing the comprehensive growth of the intellect of children, and foreseeing the necessity of forming his/her intercultural competence, which will ensure efforts, synergetics on intercultural communication. The process of forming the intercultural competence of future teachers in higher education institutions is based on fundamental approaches: systemic, competence, cultural, multicultural, cultural conductivity.

Systemic one provides the integrity, interconnection, interdependence of all stages and components of the process of formation of the intercultural competence of future educators (purpose, concept, content, forms, methods, technologies, monitoring, evaluation, outcome). The competence approach enables the intercultural competence formation of future educators through the acquisition of key cultural competences in the context of ethno-cultural space. Cultural-oriented - recognition of the priority of culture in the educational process; formation of norms of behavior, taking into account national and civil traditions on the basis of ideas of spiritual and moral values. The multicultural approach is aimed at recognizing the uniqueness of ethnic cultures, preserving them, and facilitating integration processes, intercultural communication, creating a collective socio-cultural space, building respect for other cultures, tolerance, intercultural competence, empathy. The cultural conductivity approach assumes the need to educate children in accordance with the requirements of modern advanced culture.

The formed intercultural competence of the personality of the teacher of the new Ukrainian school has its own peculiarities, determined by the specificity of professional pedagogical activity, namely: a) subjectsubject intercultural interaction, the nature of which is determined by personal qualities, professionalism of the teacher, peculiarities of the subject of psychological and psycho-psychological, physical, social, ethno-cultural features of $n$-th number of students in the class; b) the extreme importance of the goal of intercultural interaction - education: moral, ethical, spiritual, cultural, human values; respect for the national identity of oneself and others, as well as the development of intelligence, think- 
ing, pursuit of independent creative activity, which means - to teach children to study; c) the ability to use many traditional and innovative forms, methods, tools, technologies, trainings, teaching methods to achieve a positive result - the goal of the neighbor (specifically in this lesson) and perspective - to teach the child to think and work independently.

The future educator, who has mastered the theoretical foundations of intercultural communication, has practical knowledge, skills and own experience, formed intercultural competence, working in a classroom, where there are representatives of different ethnic communities, is designed to: a) create in the educational environment such conditions that would facilitate adaptation of the child to changes in his or her environment, in the educational process (not native, another language of instruction, other ethno-cultural features, traditions); b) to educate students in a spirit of respect for carriers of other cultures, for co-operation and equality, for openness and democracy in communication and, thus, to motivate and encourage children to study.

Thus, the intercultural competence of the teacher of the new Ukrainian school contributes to the success not only in intercultural interaction, but also in achieving the desired results, the effectiveness of professional and pedagogical activity.

It is important, that future teachers of the new Ukrainian school, using the invaluable experience of outstanding educators of the past and present, realizing that they "stand on the shoulders of the giants", would build up, would be the authors of their own pedagogical "handwriting", a style determined and taught by the subject features of the author. But the common feature of such projects is the purpose - to teach children to think, to "acquire" knowledge independently, to be a creative worker.

The use of differentiated and individual approach, heuristic conversation as a question-and-answer form of studying, in which the teacher does not inform the students of ready knowledge, but compels them, on the basis of previous knowledge, certain life experience and motivated thinking activity, independently to come to new concepts, are another ways and factors of pedagogical activity effectiveness. Updating the problems of the subject of study, motivation, effective organization of the educational process and independent work of students; optimization and authorization of methods, teaching aids and diagnostics of students' knowledge; improvement and diversification of educational and methodological support; intercultural competence of the teacher - priority areas, ways of increasing the effectiveness of the teacher's work.

Using an individual approach to the child's personality in the studying process, using various methods, differentiated tasks, showing patience, interest in the personality of the child, the teacher increases the effectiveness of the educational and cognitive process, which results in the enrichment of the subjects of this process. The student asserts him/herself, shows confidence in his/her abilities, is not afraid to make mistakes, expresses his/her own opinion, and the teacher practically learns the psychology of children and gains the professional experience.
Interactive teaching methods contribute to the development of the child's thinking activity, make it possible to "turbo-mode" the educational and cognitive process, unlike the formal implementation of the content of the program. As a result, the subjects of the educational and cognitive process achieve more: the development of communication skills, the ability to look at the root of problems, phenomena, law; ability to clearly ask questions and answer them; development of the child's intelligence.

Therefore, the position of a prominent teacher [16] regarding the purpose of effective pedagogical activity, the professionalism of the teacher and his/her warning about the danger of formalism in the educational process, "inaction at the desk", lack of proper motivation remain relevant forever. "Terrible danger - inaction at the desk; inactivity six hours a day, months and years. It corrupts, morally cripples a person / child ... and nothing can compensate for what is lost in the most important sphere, in which a person should be a worker - in the sphere of thinking" [16].

Therefore, one the first task of teachers of primary new Ukrainian school is to teach children to learn (study) easily, with pleasure, with interest, with elements of play and creativity, and thus to give a reliable start to high school students and future students of higher education institutions - start on self-education, self-development self-improvement. And that every teacher of the new Ukrainian school would be able to respond proudly and honestly on the question "what motivates you to work in school?": "The desire to be rich spiritually! I like to give myself to children. And once again get "yourself" from them - as many children in the classroom".

We also consider it necessary to point out, that the level of formation of the intercultural competence of the personality of specialists contributes not only to increasing the efficiency of their professional activity in Ukraine, but also increases the likelihood of labor migration of highly qualified specialists, since such professionals also have linguistic knowledge and skills. Preventing labor migration, retaining professionals, labor resources in Ukraine will contribute not only to the economic development of the country, aimed at increasing the material security of all strata of society, increasing funding for science, culture, but possibly other ways that are "laid" by initiative, knowledge and realism. It is important, that at the state level (employment centers, colleges, universities, academies of continuing education) open courses for retraining specialists, focusing on the state's need for specialists in new modern high-tech industries, are available. In addition, each active, intellectual specialist, using the opportunity for multiple vectors of lifelong learning, self-education, self-improvement throughout life, studying, using, extending the experience of organizing new institutions, industries and management experience, relying on creativity, critical thinking and integration of like-minded people can create new jobs to prevent labor migration and to obtain a useful end product: either in the form of a variety of materials and means, or in the form of a diversity of cultural and intellectual values. Such, in our opinion, in the study and analysis of the identified problem, ways to slow down and prevent the consequences of labor migration, as well 
as increase the welfare of conscientious workers, highly qualified specialists, pensioners, citizens of Ukraine are given.

\section{Conclusions}

Summarizing the results of the study, the article made the following conclusions.

1. On the basis of the theoretical analysis of scientific and pedagogical researches the essence of the concepts "competence", "competency", "professional competence", "intercultural competence of personality" as a member of a certain community, the carrier of its ethnoculture is specified. Competence reflects the content of a particular activity, the range of authority and responsibility for the decisions taken. "Competency" is a set of personality traits, their ability, based on knowledge, skills and experience to perform professional tasks, awareness, qualification. The components of the competency of a specialist's personality are: cognitiveinformational (knowledge, abilities, skills and experience in the professional activity); personal (orientation and ability to the chosen type of activity; analytical, critical thinking, flexibility of thinking); activity-procedural (ability to communicate; creative approach to the purpose, tasks, methods, methods of activity; independence, determination); reflexive (orientation to introspection, self-improvement)

The intercultural competence of the individual is the willingness of the individual: to go beyond one's own culture; to recognize, respect differences in perception, thinking, behavior of representatives of one's own and other's culture; to interact effectively and without conflict in the process of intercultural communication; successfully integrate into the world society.

2. The intercultural competence of the teacher is interpreted as a special integrative internal education, which ensures the teacher's readiness for the professional activity in the context of modern ethno-cultural diversity of the educational environment and is based on humanistic, moral-ethical, spiritual values, epistemological and philosophical positions. The intercultural competence of the teacher is the organic unity of interconnected and integrally interdependent cultures: worldview, spiritual, linguistic, communicative, conflicting, culture of thinking, feelings, behavior wholly with professional and pedagogical knowledge, skills, personality in the pedagogical activity.

3. The formed intercultural competence of the teacher's personality of the new Ukrainian school has its own peculiarities, determined by the specificity of the professional pedagogical activity, namely: a) subjectsubject intercultural interaction, the nature of which is determined by personal qualities, professionalism of the teacher, peculiarities of the subject of psychology teaching, psychophysiological, physical, social, ethno-cultural features of the certain number of students in the class; $b$ ) the extreme importance of the goal of intercultural interaction - education: moral, ethical, spiritual, cultural, human values; respect for the national identity of oneself and others, as well as the development of intelligence, thinking, pursuit of independent creative activity, which means - to teach children to learn; c) the ability to use many traditional and innovative forms, methods, technologies, trainings, teaching methods to achieve a positive result - the goal of the neighbor (specifically in this lesson) and perspective - to teach the child to think and work independently.

The structure of the intercultural competence of the NUS teacher's personality in the context of interethnic interaction is characterized as a unity of functionally related components: 1) value-ethical; 2) theoreticalcognitive; 3) personality-psychological; 4) language and communication; 5) procedural activity. The process of forming the intercultural competence of future educators in higher education institutions is based on fundamental approaches: a systematic one that ensures the integrity, interconnection, interdependence of all stages of formation; competence, which aims at assimilation of key cultural competences in the context of ethno-cultural space; cultural, which implies recognition of the priority of culture in the educational process, norms of behavior, based on ideas of spiritual and moral values; multicultural, aimed at recognizing and preserving the uniqueness of ethnic cultures and facilitating integration processes, intercultural communication; the cultural conduct approach assumes the need to educate children in accordance with the requirements of modern advanced culture.

4. The ways of improving the effectiveness of the pedagogical activity in the conditions of diversity of the ethnocultural environment are determined, the main of which are the following: a) the formation of practical skills, intercultural communication skills; b) the teacher's ability to create in the educational environment conditions (benevolence, tolerance, trust) that would contribute to the process of adjusting the child to changes in its environment; c) educating students in a spirit of respect for carriers of other cultures, for democracy in communication; d) creative use of the experience of outstanding teachers; e) motivation of children to thinking activities, independence in the "acquisition" of knowledge; using an individual approach to the child's personality, using interactive methods, differentiated tasks, demonstrating patience, interest in the personality of the child, the teacher increases the effectiveness of the educational and cognitive process.

5. It is established, that the multi-vector character of continuous education, self-education, selfimprovement throughout life is an important condition for slowing / stopping labor migration of personnel from Ukraine. After all, every active, intellectual specialist, using the opportunity of multi-vector continuous education, lifelong learning, studying, using, spreading the experience of organizing new affairs, institutions, industries and management experience, relying on creativity and critical thinking, can create new projects, organize workplaces to prevent labor migration and to obtain a useful end product.

Regarding the prospects of further scientific explorations, we believe that they should be implemented in the aspect of development of up-to-date educational and methodological support in all subjects of the lower grades of the NUS, which will promote the effective organization of children's independent work, motivated for educational and cognitive activity. 


\section{References}

1. Khasanova G. B. Formation of pedagogical competence of a specialist in personnel management // Kazan Pedagogical Journal. 2018. Issue 4. P. 81-83.

2. Kobseva N. I. Professional competences in the context of a competence-based approach in education // Vestnik Orenburgskogo Gosudarstvennogo Universiteta. 2018. Vol. 217, Issue 5. P. 36-42. doi: http://doi.org/10.25198/1814-6457-217-36

3. Polishchuk V. A. Training of the usa future social workers for the researching of multicultural environment as a part of intercultural competece formation // Scientific Bulletin of Uzhgorod University. Series: "Pedagogy. Social work". 2016. Vol. 2, Issue 39. P. $183-185$.

4. Danyshenko O. S. The issue on the acquisition of intercultural compatance: ameracan approach // Investments: Practice and Experience. 2015. Issue 24. P. 148-153. URL: http://nbuv.gov.ua/UJRN/ipd_2015_24_33

5. Yureva K. A., Tischenko O. M. The sphere of competence, competence, teacher's inter-cultural competence: essence and content // Means of educational and research work. 2014. Issue 42. P. 169-182.

6. Kozhevnikova A., Dudko Y., Golubenko N. Intercultural competence of the modern teacher as an important factor of successful pedagogical activity // Scientific Bulletin of Melitopol State Pedagogical University. 2016. Issue 2 (17). P. 120-125.

7. Branitska T. Intercultural competence as an important factor of professional activity of social sphere specialists // Scientific Bulletin of Uzhhorod University. Series: «Pedagogy. Social Work». 2019. Vol. 1, Issue 44. P. 18-22. doi: http://doi.org/10.24144/2524-0609.2019.44.18-22

8. Horuzha L. L. Teacher ethical development: textbook. Kyiv: Academic Publishers, 2012. 208 p.

9. Raven J. Competence in contemporary society: identification, development and implementation. Moscow: Kogito-Center, 2013. 396 p.

10. Sadohin A. P. Introduction in the Theory Intercultural Communication: textbook. Moscow, 2014. $254 \mathrm{p}$.

11. Slyusarenko O. M. Qualification Criteria of Competence: Conceptual and Methodological Aspects // Competence in Educational Inquiries: An Philosophy of Education. 2009. Issue 1-2 (8). P. 287-299. URL: https://cyberleninka.ru/article/n/ kvalifikatsiyna-kriterialnist-kompetentnosti-ponyatiyno-metodologichni-aspekti

12. Slastenin V. A. Introduction to pedagogical axiology: textbook. Moscow: Academy, 2009. 192 p.

13. Drach I. I. Basic approaches to determining the professional competence of the teacher // Modern information technologies and innovative teaching methods in the training of specialists: methodology, theory, experience, problems. 2012 . Issue 32. P. 9-14.

14. Kegeyan S. E. Intercultural communication in the workplace and the role of communication in an organization // International Journal of Professional Science 2016. № 2. URL: http://scipro.ru/article/03-02-16

15. Gitimu P. N. Intercultural Communication: Its Importance to Various Career Fields and Perspective by Various Authors // Online Journal for Workforce Education and Development. 2005. Vol. 1, Issue 2. URL: https://opensiuc.lib.siu. edu/ojwed/vol1/iss2/4/

16. Sukhomlinsky V. A. Pedagogical search. Moscow: Pedagogy, 1987. 544 p.

Received date 24.02.2020

Accepted date 25.05.2020

Published date 31.07.2020

Branitska Tetiana, Doctor of Pedagogical Sciences, Head of Department, Department of PsychologicalPedagogical Education and Social Sciences, Municipal higher educational institution "Vinnitsa Academy of Continuing Education", Pyrohova str., 56, Vinnytsia, Ukraina, 21018

E-mail: tatjanarom4@gmail.com

Nataliia Logutina, PhD, Lecturer, Department of Foreign Languages with Latin Course and Medical Terminology, National Pirogov Memorial Medical University, Pirogova str., 56. Vinnitsya, Ukraine, 21018

E-mail: natalia.logutina@gmail.com 